\title{
Complement C4-A
}

National Cancer Institute

\section{Source}

National Cancer Institute. Complement C4-A. NCI Thesaurus. Code C128865.

Complement C4-A (1744 aa, $193 \mathrm{kDa}$ ) is encoded by the human C4A gene. This protein plays a role in both host defense and inflammation. 